\title{
Ryszard Miazek
}

Muzeum Historii Polskiego Ruchu Ludowego

\section{Siedemdziesiąta rocznica urodzin i pięćdziesiąta rocznica pracy naukowej i zawodowej doktora Janusza Gmitruka}

W siedzibie Muzeum Historii Polskiego Ruchu Ludowego w Warszawie 4 lipca 2018 r. odbyła się uroczystość zorganizowana z okazji jubileuszu 70. rocznicy urodzin oraz 50-lecia pracy naukowej i zawodowej dyrektora Muzeum - dr. Janusza Gmitruka, połączona z promocją dedykowanego Jubilatowi kolejnego numeru „Roczników Dziejów Ruchu Ludowego” - periodyku naukowego Zakładu Historii Ruchu Ludowego, wydawanego od roku 1959.

Organizatorami obchodów jubileuszowych było Muzeum Historii Polskiego Ruchu Ludowego, Wszechnica Świętokrzyska w Kielcach, Ludowe Towarzystwo Naukowo-Kulturalne oraz Kolegium Redakcyjne „Roczników Dziejów Ruchu Ludowego”. Uroczystość zgromadziła liczne grono współpracowników i przyjaciół Jubilata, który od najwcześniejszych lat pracy zawodowej związał się z politycznym ruchem ludowym.

Drogę życiową i bogaty dorobek pracy zawodowej i naukowej dr. Janusza Gmitruka przedstawił w okolicznościowej laudacji prof. Romuald Turkowski. Poniżej zamieszczamy skrót opublikowanej w dedykowanym numerze „Roczników” obszernej biografii naukowej Jubilata, która - oprócz wątków osobistych - zawiera wiele interesujących faktów z historii ruchu ludowego, przybliża historię współtworzących go organizacji i instytucji oraz przywołuje pamięć wielu działaczy.

\section{Biografia naukowa Janusza Gmitruka}

Janusz Gmitruk urodził się 17 lutego 1948 r. we wsi gminnej Świniarów koło Łosic; w okolicy, która słynęła z niepodległościowych i patriotycznych tradycji, walki o ziemię, wolność i wiarę. W pamięci mieszkańców Świniarowa zachowały się wspomnienia z uroczystości religijnych odprawianych w lesie, gdzie udzielano komunii, chrztów, łączono małżeństwa. Uroczystości zabezpieczały wystawione w dużej odległości od lasu warty, które ostrzegały przed zbliżaniem się żandarmów. Zmieniło się to po carskim ukazie o tolerancji religijnej, wydanym 30 kwietnia 1905 r., który gwarantował swobodę wyznania dla wszystkich 
mieszkańców Imperium Rosyjskiego. Wtedy to wielu unitów ziemi łosickiej przeszło na wiarę katolicką. Powstała parafia pod wezwaniem św. Zygmunta. Mieszkańcy Świniarowa aktywnie uczestniczyli w budowie kościoła w Łosicach. W tej świątyni w 1948 r. chrzest przyjął Janusz Gmitruk. Nadane mu imię związane było z tradycją mazowiecką. Ksiądz początkowo nie chciał się na nie zgodzić, bo nie było go w kalendarzu świętych.

Bogata i skomplikowana przeszłość ziemi rodzinnej rozbudzała w sposób naturalny zainteresowania Janusza historią. W jego pamięci na trwałe zapisały się opowiadania dziadka Bazylego o rewolucji październikowej, o jego przeżyciach po wysiedleniu w czasie wycofywania się Rosjan z Królestwa Polskiego w 1915 r. Przebywał nad Wołgą, a do rodzinnej wsi Drewnówka, w powiecie Brześć nad Bugiem, wrócił dopiero w 1922 r. Wieś była spalona przez wycofujących się Rosjan, a pola porośnięte młodą brzeziną nie nadawały się do uprawy. Dziadek razem z sąsiadem z okolicznej wsi, Andrzejem Marczukiem, postanowili więc szukać pracy za Bugiem, w powiecie siedleckim. Wynajmowali się do robót sezonowych na roli. Byli także biegli w ciesiołce, więc dodatkowo naprawiali domy i zabudowania gospodarcze. W 1926 r. znaleźli zatrudnienie i przystań na całe życie w rodzinie Jana Żuka, bogatego gospodarza ze wsi Świniarów, w powiecie Konstantynów. Jan Żuk miał sześć córek na wydaniu i jednego syna. Dziadek Bazyli wybrał na żonę Felicję, a jego kolega Andrzej - Janinę. Jan Żuk, jako wiana wydzielił młodym małżonkom samodzielne 5-hektarowe gospodarstwa.

W rodzinie Gmitruków tradycja pracy społecznej przenoszona była z pokolenia na pokolenie. Dziadek Bazyli był działaczem Polskiej Partii Socjalistycznej. Ojciec, Paweł, człowiek wszechstronnie utalentowany, społecznik, wybierany był na sołtysa. Matka, Genowefa, mądra i pracowita opiekunka ogniska domowego, po śmierci męża prowadziła samodzielnie gospodarstwo. Dzięki rodzicom Janusz zapamiętał dzieciństwo jako okres życia bardzo szczęśliwy i bezpieczny.

Po ukończeniu szkoły podstawowej Janusz Gmitruk ukończył Liceum Ogólnokształcące im. Józefa Pietruczuka w Łosicach. Patron szkoły był jej organizatorem, legendą ziemi podlaskiej, synem chłopskim, poetą, nauczycielem i ludowcem, wielkim humanistą, wrażliwym na ludzką krzywdę. W czasie II wojny światowej pomagał skazanym na zagładę jeńcom radzieckim, Żydom i osobom prześladowanym. Jego dom w Hadynowie był twierdzą ludowej konspiracji.

Profesorowie Wolnej Wszechnicy Polskiej w Warszawie prowadzili w Hadynowie tajne zajęcia studiów wyższych, w których uczestniczyli ludowi działacze i partyzanci. Nasycenie powiatu siedleckiego tajnymi kompletami na poziomie szkoły średniej i wyższej dało kadry do tworzenia po wojnie szkół średnich. Józef Pietruczuk wykorzystał ten fakt, tworząc Samorządowe Liceum Ogólnokształcące w Łosicach. Osłaniał działalność szkoły, przyjmując funkcję burmistrza. Szkoła rozpoczęła rok szkolny 1944 i działała nadal, mimo że Józef Pietruczuk został skrytobójczo zamordowany przez pospolitych bandytów w 1945 r.

Zainteresowanie szerszymi dziejami Polski rozbudził w Januszu licealny nauczyciel historii - Ignacy Zawada, natomiast Marian Kwiatek - dyrektor Liceum, przybliżył do Związku Młodzieży Wiejskiej i politycznego ruchu chłopskiego. 
W czasie nauki w Łosicach Janusz działał w Związku Harcerstwa Polskiego. Szkoła w Łosicach rozbudziła w nim pragnienie podjęcia studiów historycznych. Rozpoczął je w Instytucie Historycznym na Uniwersytecie Warszawskim w 1966 r. Pracowała tam wówczas znakomita kadra naukowa, kierowana m.in. przez prof. Aleksandra Gieysztora, prof. Henryka Samsonowicza.

Szczególne znaczenie dla utrwalenia zainteresowań badawczych młodego studenta miały obozy naukowe organizowane przez Instytut i Zarząd Uczelniany Związku Młodzieży Wiejskiej (ZMW) na terenie powiatu siedleckiego. W organizacji studenckich wyjazdów pomagał pierwszy powiatowy komendant Batalionów Chłopskich - Franciszek Duczek, przedwojenny prezes Zarządu Powiatowego Związku Młodzieży Wiejskiej RP „Wici”, a także jego zastępca w komendzie powiatowej - Stanisław Jaszczuk ze Stoku Ruskiego, przed wojną prezes Zarządu Powiatowego Centralnego Związku Młodej Wsi „Siew”. Pomocy i wsparcia młodym badaczom udzielał też Komitet Powiatowy ZSL w Siedlcach. W jego strukturach działało i pracowało wówczas wielu byłych działaczy konspiracyjnego ruchu ludowego, Batalionów Chłopskich i członkiń Ludowego Związku Kobiet. Zebrana wówczas dokumentacja z lat okupacji zachowała się, została przekazana do zbiorów Archiwum Zakładu Historii Ruchu Ludowego w Warszawie. Rozmowy z byłymi ludowymi konspiratorami prowadzone były w przyjaznej ludowej i patriotycznej atmosferze. Dzięki nim Janusz zrozumiał, jak wielką wartością jest ruch ludowy, a to przesądziło o jego dalszych losach.

Na uczelni Janusz Gmitruk był aktywnym działaczem ZMW. W uczelnianym pomieszczeniu zorganizował laboratorium fotograficzne, służące dokumentowaniu działalności organizacji. W tym czasie opiekun naukowy obozu studenckiego prof. Józef Ryszard Szaflik zainteresował go bliżej dziejami ruchu ludowego. Osobowość Profesora wywarła też niebagatelny wpływ na dalsze losy Janusza. W grudniu 1970 r. wstąpił on do Uniwersyteckiej Organizacji ZSL. Profesor J.R. Szaflik zainspirował go do napisania pracy magisterskiej na temat ruchu oporu w powiecie siedleckim.

Praca magisterska Janusza pt. „Konspiracyjny ruch ludowy w powiecie siedleckim 1939-1944” została nagrodzona w konkursach historycznych i opublikowana w numerze 14. „Roczników Dziejów Ruchu Ludowego”. Dla młodego absolwenta UW stała się przepustką do Zakładu Historii Ruchu Ludowego NK ZSL, w którym został zatrudniony od 1 października 1971 r. Zakład powołano w 1960 r. jako wydział NK ZSL. Miał daleko posuniętą autonomię w badaniach naukowych. W zamyśle Czesława Wycecha - inicjatora powstania i mecenasa Zakładu, placówka ta miała za zadanie prowadzenie i inspirowanie badań naukowych nad historią ruchu ludowego, wsi i chłopów, gromadzenie i zabezpieczanie materiałów źródłowych, współdziałanie i wzbogacanie tożsamości historycznej w bieżącej działalności ideowo-politycznej Stronnictwa.

Od chwili powstania Zakładu tworzono bazę archiwalną i bibliotekę. Najcenniejszą część jego zbiorów stanowią archiwalia. Biblioteka to wiele tysięcy broszur, tytułów prasy i książek, niekiedy unikalnych egzemplarzy. Januszowi powierzono opiekę nad Archiwum Ikonograficznym i II wojny światowej. Pracę 
zawodową łączył z aktywną działalnością społeczną. Został wybrany na ławnika w Sądzie Rejonowym w Warszawie, gdzie przez 10 lat uczestniczył w rozprawach sądowych.

W swojej pracy naukowej z wielką cierpliwością poszukiwał obiektywnej prawdy nie tylko w zaciszu archiwów, lecz także w pamięci żyjących jeszcze wówczas świadków i bezpośrednich uczestników wydarzeń. Zebrał setki relacji, zainspirował też wiele bezcennych dziś wspomnień. Efektem tego są pionierskie monografie i artykuły naukowe jego autorstwa, poświęcone m.in. dziejom konspiracyjnego ruchu ludowego na Kielecczyźnie (trzy wydania) i rodzinnym Podlasiu. Pozyskiwał do zbiorów Archiwum ZHRL nieznane fotografie, konspiracyjne wydawnictwa i dokumenty. Poznał wówczas wielu wspaniałych ludowców - przywódców konspiracyjnego ruchu ludowego na Kielecczyźnie: Franciszka Kamińskiego - pierwszego organizatora SL „Roch” i BCh, późniejszego komendanta głównego tej formacji; Czesława Ponieckiego - przewodniczącego wojewódzkiego SL „Roch”; Stanisława Jagiełłę - komendanta Okręgu III BCh kieleckiego, oraz wielu dowódców oddziałów partyzanckich: Eugeniusza Fąfarę, Piotra Pawlinę, Antoniego Piwowarczyka, Józefa Abramczyka, Jana Sońtę i innych.

W pracy badawczej spotykał się z niezwykłą serdecznością nie tylko ze strony działaczy, lecz także i historyków ziemi kieleckiej: Mieczysława Adamczyka, Stefana Józefa Pastuszki, Longina Kaczanowskiego, Stanisława Durleja i wielu innych. Wojewódzkie Komitety ZSL w Radomiu i Kielcach prowadziły bardzo ożywioną działalność oświatową i propagandową. Organizowano wiele spotkań, prelekcji z byłymi żołnierzami BCh, wydawcami prasy ludowej, członkiniami LZK. Janusz Gmitruk był często referentem na tych spotkaniach. Poznawał coraz więcej działaczy. Stawał się częścią ludowcowej rodziny ziemi kieleckiej.

Pracę doktorską pt. „Konspiracyjny ruch ludowy na Kielecczyźnie 19391945” obronił na Uniwersytecie Warszawskim w 1979 r. Stało się to dzięki pomocy materialnej uczelni, a także opiece naukowej prof. J.R. Szaflika. Dysertacja została nagrodzona i wydana przez Ludową Spółdzielnię Wydawniczą w 1980 r. Trzecie, rozszerzone wydanie książki ukazało się pt. „Ku zwycięstwu. Konspiracyjny ruch ludowy na Kielecczyźnie 1939-1945” (2003), dzięki wsparciu finansowemu Wszechnicy Świętokrzyskiej w Kielcach.

Publikacja pracy doktorskiej Janusza Gmitruka przez LSW, a potem aktywny udział autora w jej promocji w terenie, zbliżyły go do tego wydawnictwa. Ludowa Spółdzielnia Wydawnicza była wówczas potężnym przedsiębiorstwem o charakterze ogólnokrajowym, jednym spośród czterech liczących się w kraju wydawnictw. Była doskonale zorganizowaną spółdzielnią, kierowaną przez sprawny Zarząd, którego prezesem i redaktorem naczelnym był Leon Janczak - wiciarz, partyzant, więzień obozów koncentracyjnych, spółdzielca, a jednocześnie ideowy i wytrawny polityk.

Ludowa Spółdzielnia Wydawnicza zajmowała w tym czasie także szczególne miejsce w ruchu ludowym. Utworzona przez ludowców i przez nich kierowana została w 1959 r. usamodzielniona. Nadano jej formułę spółdzielczą, najbezpieczniejszą w ówczesnym systemie politycznym. Walne Zgromadzenia 
Członków LSW, odbywające się corocznie pod koniec czerwca, były „małymi kongresami ruchu ludowego”. Na jego obradach gromadzili się przybywający z całego kraju spółdzielcy, członkowie stronnictwa, a także tzw. wolni ludowcy, znajdujący się poza strukturami ZSL na tzw. emigracji wewnętrznej, pracownicy LSW, artyści i pisarze. W latach 80. XX w. LSW miała liczną (27-osobową) Radę Nadzorczą (odnawianą o 9 członków na każdym walnym zgromadzeniu), której zadaniem było nadzorowanie działalności trzyosobowego Zarządu Spółdzielni.

W roku 1983 Janusz Gmitruk został sekretarzem, a potem wiceprzewodniczącym Rady Nadzorczej LSW. Dzięki temu zdobywał nowe doświadczenie spółdzielcze i samorządowe, poznał wielu legendarnych działaczy ruchu ludowego, wybitnych społeczników: Marię Maniakównę, Helenę Brodowską, Stefana Pawłowskiego i innych. LSW, stopniowo uniezależniając sie od ZSL, stawała się jednym z samodzielnych ośrodków ruchu ludowego. Janusz zaangażował się w obronę spółdzielczego charakteru wydawnictwa i jego majątku wobec prób przejęcia jej przez polityków. Do Rady Nadzorczej LSW powrócił jeszcze pod koniec lat 90. XX w., jako jej przewodniczący, ratując to, co pozostało z wydawnictwa po transformacji ustrojowej.

Jedną z form aktywności zawodowej Janusza Gmitruka w tym czasie było organizowanie w gmachu ZSL wspólnie z kolegą z ZHRL, Janem Sałkowskim, wystaw fotograficznych, których rokrocznie prezentowano kilkanaście.

Ważnym wydarzeniem w życiu Janusza była współpraca przy kolejnym odrodzeniu Związku Młodzieży Wiejskiej, 3 grudnia 1980 r. Stało się to dla niego inspiracją do prowadzenia w latach 1981-1990 badań nad dziejami wiejskiego ruchu młodzieżowego w Zarządzie Krajowym ZMW. Od 1982 r. kierował pracami Krajowej Komisji Historycznej ZK ZMW, która zorganizowała blisko 50 konferencji naukowych, wydawała publikacje, materiały źródłowe oraz periodyk „Roczniki Dziejów Ruchu Młodowiejskiego”.

Inną płaszczyzną aktywności Janusza były wykłady dla nauczycieli historii w ramach Towarzystwa Wiedzy Powszechnej na terenie województwa bialsko-podlaskiego. Bardzo popularne były wówczas tematy dotyczące tzw. białych plam w najnowszej historii Polski. W tym czasie trwała też kilkuletnia współpraca na Uniwersytecie Przyrodniczo-Humanistycznym w Siedlcach oraz udział w pracach redakcji „Rocznika Bialskopodlaskiego”, którego przewodniczącym Kolegium Redakcyjnego był aż do śmierci prof. H. Mierzwiński.

W latach 80. XX w. na koncie dorobku naukowego dr Janusza Gmitruka pojawiały się liczne prace o charakterze syntetycznym poświęcone Batalionom Chłopskim i ich osiągnięciom militarnym w sali ogólnopolskiej, ale także i martyrologii wsi polskiej w latach wojny i okupacji.

Janusz uczestniczył aktywnie w pracach zespołu do spraw martyrologii wsi Głównej Komisji Badania Zbrodni Hitlerowskich w Polsce. Działał także w powołanym w 1984 r. Komitecie Organizacyjnym Budowy Mauzoleum Walki i Męczeństwa Wsi Polskiej w Michniowie. Te działania doprowadziły do powstania Mauzoleum, z inicjatywy dr. Janusza Gmitruka zorganizowano tam stałą wystawę pt. „Gdy płonęły niebo i ziemia” i wydano interesujący informator. Współpraca z Mauzoleum trwa do dziś. 
W 1984 r. Janusz Gmitruk współuczestniczył także w działaniach zmierzających do powołania Muzeum Historii Polskiego Ruchu Ludowego w Warszawie. Pełnomocnikiem prezesa ZSL, marszałka Romana Malinowskiego, do spraw organizacji muzeum został dr Józef Fajkowski. W kierownictwie Stronnictwa ścierały się sprzeczne poglądy na temat celów i zadań, a także podległości - zależności tej placówki i jej obsady personalnej. Linia sporu przebiegała między zwolennikami włączenia Muzeum w struktury ZSL, z zachowaniem dotacji państwowej na działalność tej placówki, a przeciwnikami tej koncepcji, którzy widzieli Muzeum jako samodzielną instytucję kultury, podległą ministerstwu, ale pod ideowym oddziaływaniem Stronnictwa. To ideowe oddziaływanie miał zapewnić dyrektor MHPRL rekomendowany każdorazowo na to stanowisko przez NK ZSL oraz Radę Muzeum, w której funkcję przewodniczącego wyznaczono dyrektorowi Zakładu Historii Ruchu Ludowego. Na inaugurację działalności MHPRL Janusz Gmitruk wspólnie z dr. Janem Sałkowskim zorganizowali pierwszą wystawę z okazji 90. rocznicy powstania ruchu ludowego w 1895 r., eksponowaną w Muzeum Etnograficznym. Natomiast na uroczystość otwarcia siedziby Muzeum w Żółtej Karczmie przy al. Wilanowskiej 204 przygotował wystawę pt. „Bataliony Chłopskie”.

W czasie transformacji ruchu ludowego w latach 1988-1989 Janusz Gmitruk był zastępcą dyrektora Zakładu Historii Ruchu Ludowego. Wspólnie z ówczesnym dyrektorem ZHRL prof. Janem Jachymkiem przygotowali koncepcję powołania Instytutu Ruchu Ludowego, składającego się z sześciu zakładów naukowo-badawczych. Docelowo przewidywano zatrudnienie 60 pracowników. Dla potrzeb Instytutu projektowano budowę osobnego obiektu na działce przy ul. Grzybowskiej 4, na zapleczu siedziby NK ZSL. Pracownie naukowe, biblioteka i archiwum połączone miały być z częścią hotelową Centralnego Ośrodka Doskonalenia Kadr ZSL. Instytut - jak planowano - miał w przyszłości zabezpieczać kształcenie kadr stronnictwa. Plany te nie zostały jednak zrealizowane z powodu braków finansowych i zmian organizacyjnych po transformacji politycznej ruchu ludowego.

Od 1 stycznia 1990 r. Janusz Gmitruk został powołany przez kierownictwo nowo powstałego Polskiego Stronnictwa Ludowego - Odrodzenie na stanowisko dyrektora Zakładu Historii Ruchu Ludowego NKW Stronnictwa. Doprowadził wówczas do przejęcia zbiorów likwidujących się struktur ZSL. Zabezpieczył je i przygotował do dalszego udostępniania. Przeprowadził ZHRL przez perturbacje polityczne roku 1990. Zakład był jedyną strukturą byłego ZSL, która przetrwała kolejne etapy zjednoczenia i zmiany w kierownictwie. Przyczyniła się do tego siła tradycji ruchu ludowego, ale też zręczność organizacyjna i polityczna dyrektora ZHRL. Mimo poważnego zmniejszenia liczby etatów, placówka ta wraz z filią w Krakowie, przez kolejne lata zachowała swoje funkcje inspiratora badań naukowych nad dziejami ruchu ludowego, prowadzenia własnych prac badawczych oraz porządkowania i udostępniania materiałów archiwalnych. Obecnie - po kolejnych zmianach organizacyjnych - Zakład niestety praktycznie przestał istnieć jako placówka naukowa. 
Z inspiracji członków Rady Naukowej ZHRL, działaczy i polityków, w 1992 r. powstało Ludowe Towarzystwo Naukowo-Kulturalne, jako kontynuacja międzywojennego Zrzeszenia Inteligencji Ludowej i Przyjaciół Wsi oraz działającego w konspiracji Związku Pracy Ludowej „Orka”. Janusz Gmitruk był współorganizatorem, założycielem, członkiem prezydium i wiceprzewodniczącym LTNK. Od czerwca 2008 r., po śmierci prof. J.R. Szaflika został prezesem Zarządu Głównego LTNK. Towarzystwo wydaje własny periodyk pt. „Myśl Ludowa”, Janusz Gmitruk kieruje pracami jego Rady Programowej.

LTNK stało się współzałożycielem Wszechnicy Świętokrzyskiej, zorganizowanej, kierowanej i rozbudowywanej przez prof. dr. hab. Mieczysława Adamczyka. Wszechnica Świętokrzyska to jedna z najlepszych niepublicznych uczelni wyższych, która wykształciła około 30 tys. absolwentów. Wielu z tych, którzy ukończyli uczelnię, odgrywa znaczącą rolę w działalności społecznej, politycznej i gospodarczej regionu. Janusz Gmitruk również współpracuje naukowo z Rektorem Wszechnicy prof. dr. hab. Mieczysławem Adamczykiem. Wspólnie wydali kilkanaście znaczących wydawnictw źródłowych.

Ludowe Towarzystwo Naukowo-Kulturalne stworzyło formułę zabezpieczającą działalność naukową i wydawniczą ZHRL. Począwszy od roku 2002 kolejne numery periodyku naukowego Zakładu - „Roczników Dziejów Ruchu Ludowego”, ukazującego się od 1959 r., wydawane były nakładem LTNK.

Od 1990 r. Janusz Gmitruk współdziałał z gen. Franciszkiem Kamińskim, honorowym prezesem PSL i przewodniczącym Ogólnopolskiego Związku Żołnierzy Batalionów Chłopskich w upamiętnianiu chłopskiego czynu zbrojnego. Jednocześnie współpracował z Urzędem do spraw Kombatantów i Osób Represjonowanych jako główny specjalista w zakresie historii Batalionów Chłopskich. Przyspieszał weryfikację wniosków o wydanie uprawnień kombatanckich byłym żołnierzom ludowej konspiracji. Weryfikował także wnioski Żydów uratowanych z getta, którym zgodnie z ustawą należały się uprawnienia kombatanckie. Kierując Zakładem Historii Ruchu Ludowego, uczestniczył w posiedzeniach NKW i Rady Naczelnej PSL. Wchodził w skład zespołu ekspertów PSL, był też doradcą w Klubie Parlamentarnym PSL.

Od 1 października 1996 r. Janusz Gmitruk rozpoczął pracę naukową i dydaktyczną w Instytucie Historii Wyższej Szkoły Rolniczo-Pedagogicznej, a od 1 października 2010 r. w Uniwersytecie Przyrodniczo-Humanistycznym w Siedlcach. Prowadził seminaria magisterskie i podyplomowe z historii najnowszej Polski. Wypromował 200 magistrów i 45 prac dyplomowych. W ramach badań statutowych nad chłopskim ruchem oporu po II wojnie światowej opublikował wiele monografii, prac źródłowych, artykułów naukowych. Prowadził także w latach 2006-2008 badania w Wyższej Szkole Biznesu i Administracji w Łukowie, kierował tam Zakładem Politologii.

Od dnia 3 września 1997 r. Minister Kultury Zdzisław Podkański powołał dr. Janusza Gmitruka, w ramach 5-letniego kontraktu, na stanowisko dyrektora Muzeum Historii Polskiego Ruchu Ludowego. Od tego roku Muzeum zmieniło formułę działalności, otworzyło się na nowe środowiska naukowe, unowocześniło 
swoją działalność, odmłodziło kadrę pracowników, którzy realizują w nim swoje ambicje naukowe, przygotowują dysertacje doktorskie, publikują książki i artykuły. Dyrektor MHPRL jest zarazem redaktorem naczelnym periodyku „Rocznika Historycznego Muzeum Historii Polskiego Ruchu Ludowego”. W ramach prac badawczych nad dziejami politycznego ruchu chłopskiego Muzeum wydało około 450 tytułów publikacji, zorganizowało około 400 wystaw. Stało się też liczącym się w kraju ośrodkiem wydawniczym. Pełni rolę ludowego centrum muzealnego, przy którym działają liczne towarzystwa.

ZHRL i MHPRL współpracują z uczelniami państwowymi i prywatnymi, wydają w koedycji monografie i wydawnictwa źródłowe. Przy współpracy z Instytutem Gospodarstwa Społecznego Szkoły Głównej Handlowej z dr. Andrzejem Budzyńskim na czele Janusz Gmitruk zorganizował konkurs na pamiętniki nowego pokolenia chłopów polskich rozpisany na 100-lecie ruchu ludowego, nad którym patronat objął ówczesny marszałek Senatu Adam Struzik. Plon konkursu był pokaźny. Nadesłane prace zostały wydane w 15 tomach nakładem ZHRL, LTNK, IGS SGH i MHPRL.

Po 1989 r. do badań naukowych Zakładu Historii Ruchu Ludowego wpisano działania zmierzające do upamiętnienia ukraińskiego ludobójstwa na Kresach Wschodnich. Ruch ludowy miał ku temu moralny obowiązek, gdyż miejscem zbrodni ludobójstwa nacjonalistów ukraińskich były nie miasta, lecz polskie wsie, a ich ofiarami stali się przede wszystkim polscy chłopi i ich wielodzietne rodziny, a wśród nich wielu działaczy ruchu ludowego - przedwojennego Stronnictwa Ludowego i Związku Młodzieży Wiejskiej RP. Galicja była kolebką ruchu ludowego na ziemiach polskich i przewodziła mu zarówno w dobie rozbiorów, jak i w latach międzywojennych, a w niektórych dziedzinach również w latach okupacji, kiedy struktury Batalionów Chłopskich na tych terenach zorganizowały samoobrony. Do dziś nie jest znana pełna liczba ofiar ukraińskiego ludobójstwa, jak i nie jest znana większość nazwisk pomordowanych ludowców.

Priorytetem Zakładu była jednak wówczas potrzeba badań nad walką i martyrologią Polskiego Stronnictwa Ludowego - wielkiej, ludowej, narodowej i chrześcijańskiej partii politycznej zniszczonej przez komunistów w latach 19451947.

W 2000 r. nawiązał kontakt z Zakładem Historii Ruchu Ludowego płk Jan Niewiński - przewodniczący Kresowego Ruchu Patriotycznego, weteran walk z Ukraińską Powstańczą Armią. Był on jednym z głównych inspiratorów większości działań o charakterze społecznym i politycznym, mających na celu przywrócenie prawdy o tragedii ludności polskiej na Kresach Wschodnich i upamiętnienia ofiar w formie monumentalnego pomnika w Warszawie oraz w publikacjach książkowych. Janusz Gmitruk doprowadził do podpisania 7 kwietnia 2006 r. umowy między Polskim Stronnictwem Ludowym a Kresowym Ruchem Patriotycznym, przewidującej kultywowanie narodowych tradycji i zapewnienie szacunku osobom szczególnie zasłużonym dla Polski. 
Pod koniec lat 90. XX w. Janusz Gmitruk wspólnie z Kazimierzem Janikiem reaktywował Konwent ZMW, który stał się ponadpartyjną platformą działań, gromadzącą trzy pokolenia byłych działaczy Związku. Przez 10 lat, w pierwszą sobotę stycznia każdego roku, organizowane były w Domu Chłopa w Warszawie spotkania pokoleń, na które przybywało z całej Polski czasem ponad 1000 działaczy. Na spotkaniach tych prezentowane były wystawy Muzeum Historii Polskiego Ruchu Ludowego, promowano wydawnictwa poświęcone dziejom ruchu młodowiejskiego. Wręczane były odznaczenia. Powstała wtedy inicjatywa przygotowania „Słownika biograficznego polskiego ruchu młodowiejskiego” (do tej pory ukazały się trzy tomy).

W latach 2004-2008 Janusz Gmitruk kierował panelem ekspertów „Kultura” w Urzędzie Marszałkowskim Województwa Mazowieckiego. Od 1992 r. współdziała z Zarządem Głównym Związku Ochotniczych Straży Pożarnych, gdzie jest członkiem prezydium i wiceprzewodniczącym Komisji Historycznej i współredaktorem jej periodyku pt. „Zeszyty Historyczne ZG ZOSP”. Jest współzałożycielem i członkiem władz towarzystw naukowych - m.in.: Stowarzyszenia Historyków Wojskowości, Stowarzyszenia Dziennikarzy im. W.S. Reymonta, a także kolegiów pism - m.in.: „Rocznik Bialskopodlaski”, „Niepodległość i Pamięć”, „Polski Uniwersytet Ludowy”.

Janusz Gmitruk od lat współpracuje także z Towarzystwem Przyjaciół Ziemi Łosickiej w badaniach naukowych na temat tego regionu. Popularyzuje jego dzieje w periodykach naukowych i wydawnictwach z serii „Dzieje Ziemi Łosickiej”.

Owocnie współpracował w badaniach naukowych nad najnowszymi dziejami Polski z Oddziałem Instytutu Pamięci Narodowej w Rzeszowie. Wspólnie z tymże Oddziałem od 2003 r. wydano pięciotomową serię książek pt. „Represje wobec wsi i ruchu ludowego w latach 1944-1989”, będącą pokłosiem wspólnych konferencji naukowych. Podobną współpracę podjęto z oddziałami terenowymi IPN w Krakowie i w Lublinie, czego efektem były wspólne publikacje - monografie i wybory dokumentów.

W 2008 r. Janusz Gmitruk podpisał umowę o współpracy naukowej i wydawniczej z Januszem Kurtyką, prezesem IPN. Efektem tej współpracy z IPN były wybory dokumentów, monografie, biografie i albumy fotograficzne, w tym trzytomowe dzieło „Stanisław Mikołajczyk w dokumentach aparatu bezpieczeństwa”, poprzedzone wstępem pióra Janusza Gmitruka.

Jako dyrektor Zakładu Historii Ruchu Ludowego i Muzeum Historii Polskiego Ruchu Ludowego, a potem przewodniczący Zarządu Głównego Ludowego Towarzystwa Naukowo-Kulturalnego Janusz Gmitruk był współorganizatorem ogólnopolskich badań nad dziejami ruchu ludowego, w tym pięciu Kongresów Historyków Wsi i Ruchu Ludowego - w Rzeszowie (1995 r.), w Lublinie (2000 r.), w Pułtusku (2006 r.), w Warszawie (2010 r. i 2015 r.). Trwałym i cennym efektem tych wydarzeń naukowych są wielotomowe publikacje pokongresowe. Jako dyrektor Muzeum Historii Polskiego Ruchu Ludowego aktywnie wspiera środowisko artystów, organizując od kilku lat tematyczne plenery malarskie. 
Janusz Gmitruk opublikował do tej pory ponad 50 książek, 100 artykułów naukowych i ponad 200 popularnonaukowych w prasie. Był organizatorem lub współorganizatorem 50 wystaw. W czasie swej pracy naukowej otrzymał liczne odznaczenia, nagrody i wyróżnienia w tym Krzyż Kawalerski Orderu Odrodzenia Polski.

Liczący ponad 1000 stron periodyk Zakładu Historii Ruchu Ludowego - numer specjalny „Roczników Dziejów Ruchu Ludowego” - pomieścił ponad 60 artykułów znakomitych badaczy dziejów wsi i ruchu ludowego, współpracowników i sympatyków ZHRL i MHPRL. Tak liczny odzew na apel redakcji, aby w ten zwyczajowy sposób uczcić Jubilata, świadczy o żywej dla niego sympatii i uznaniu w środowiskach, z którymi jest związany.

Adres mailowy autora: rmiazek@wp.pl

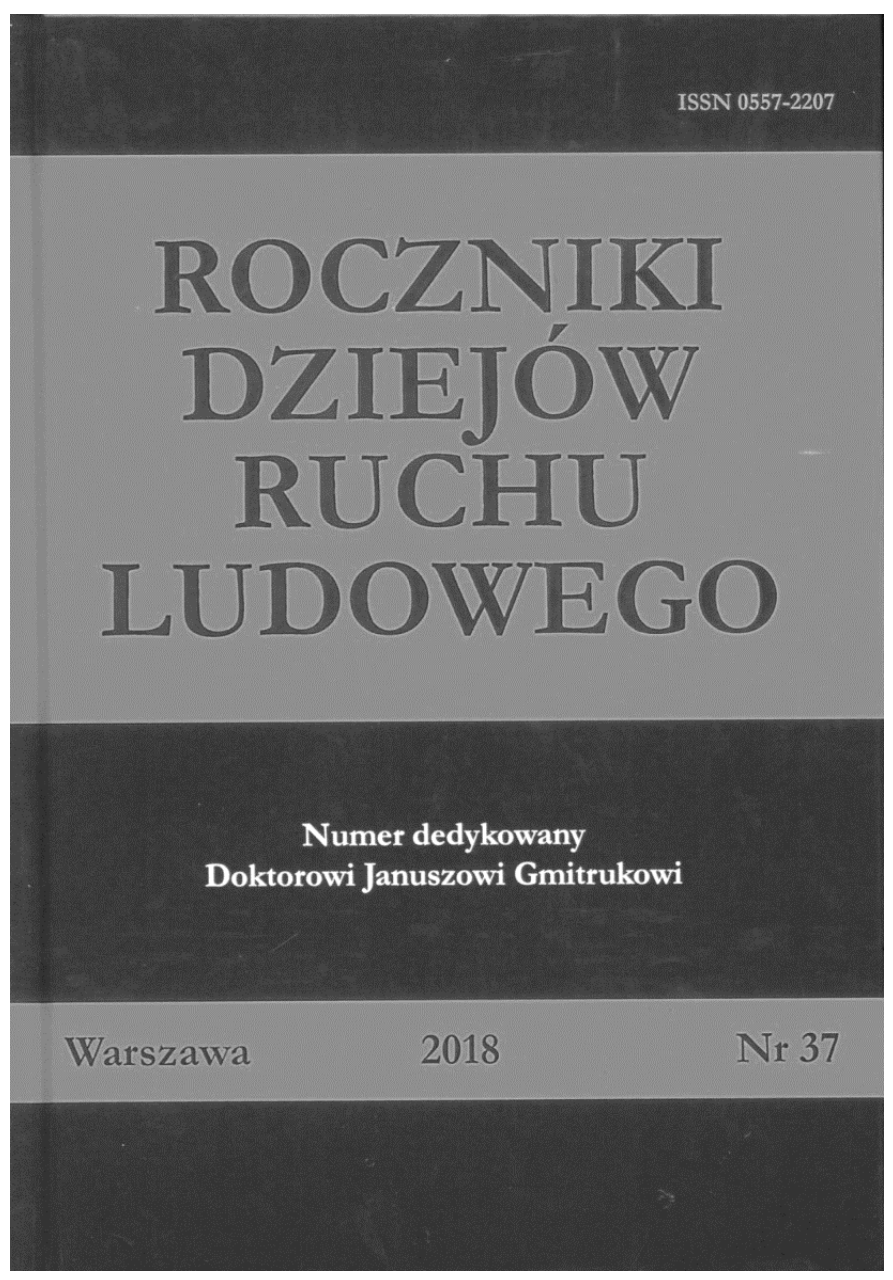


Kolega

\section{dr Janusz Gmitruk}

Dyrektor

Muzeum Historii Polskiego

Ruchu Ludowego

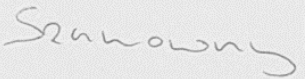

$$
\text { Koldego Januszu, }
$$

$z$ okazji jubileuszu 70.rocznicy urodzin oraz 50. rocznicy pracy naukowej i zawodowej prosze przyjać jak najlepsze życzenia i gratulacje.

Polskie Stronnictwo Ludowe bardzo pozytywnie ocenia dorobek Kolegi $w$ zakresie dokumentowania $i$ popularyzowania wkładu ludowców i ruchu ludowego w tworzeniu zrębów niepodległego Państwa Polskiego, walki o godne miejsce chłopów i wsi w II Rzeczypospolitej, heroicznej postawy $w$ czasie okupacji hitlerowskiej, odbudowy kraju ze zniszczeń wojennych $i$ awansu cywilizacyjnego wsi oraz umacniania demokracji po roku 1989.

Liczne publikacje Muzeum Historii Polskiego Ruchu Ludowego $i$ Zakładu Historii Ruchu Ludowego przybliżyły Polakom, a szczególnie młodemu pokoleniu sylwetki wybitnych ludowców na czele $z$ Wincentym Witosem, Maciejem Ratajem, Stanisławem Mikołajczykiem i Franciszkiem Kamińskim.

Serdecznie dziękuje Koledze za długoletnia współprace z Rada Naczelna, Naczelnym Komitetem Wykonawczym oraz Klubem Parlamentarnym PSL, która zaowocowała licznymi konferencjami naukowymi i wystawami.

Prosze przyjać życzenia dalszych, długich lat życia, dalszej owocnej aktywności naukowej oraz szczéścia $w$ życiu rodzinnym.
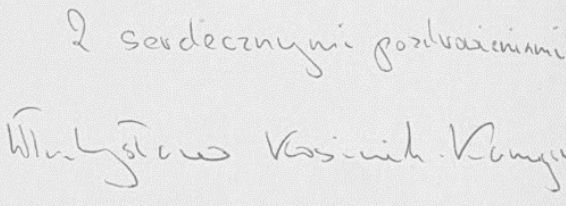


\section{Szanowny Pan}

dr Janusz Gmitruk

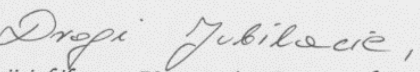

$z$ okazji ju6ileuszu 70. rocznicy Pana urodzin oraz 50-lecia pielegnowania doro6ku ruchu ludowego, przypadających w stulecie odzysķania niepodlegfości przez Polskẹ, pragnę zfożyć najserdeczniejsze życzenia zdrowia, radości i spefnienia marzeń.

W Pańskim życiorysie wyróżniaja się dwa watkỉ: dziafacza Zwiqzku Mfodzieży Wiejskiej i historyka, Gadacza dziejów Batalionów Chłopskich. Doro6ek naukowy oraz zawodowy budza szacunek, zwłaszcza dziefo zwieńczone funkcją Dyrekttora Muzeum Historii Polskiego Ruchu Ludowego, sprawowanq̨ od 1997 roku aż do dziś. Szczególnie ważne dla nas, mieszkańców Mazowsza, kierowanie tą placówka przejąf Pan od jej twórcy - Józefa Fajkowskiego i uczynif ją krajowym centrum fistorii oraz kultury ludowej. Dzisiaj to niezwykfy organizator przedsięwzięć naukowych i muzealnych, wielu cennych akcji, wystaw $i$ jedynych $w$ swoim rodzaju spotkań $w$ plenerze. Jakgo oso6a otwarta, skromna i ciepfa zyskaf Pan przyjacióf nie tylko w muzeach na Mazowszu. Pańska wszechistronna dziafalność przyczynifa się do krzewienia patriotyzmu i zachowania pamięci o postaciach ważnych dla Kraju, dla Mazowsza i dla ruchu ludowego.

Dzięßuję za dziefa Pana życia pefne pasji, determinacji i mifości do ludzi. Serdecznie gratuluję osiagnięć, życzę realizacji nowych projeßțów i pomyśności w życiu osobistym. $\mathcal{N i e c h ~ t e n ~ u r o c z y s t y ~ d z i e n ́ ~ d o s t a r c z y ~ P a n u ~ n i e z a p o m n i a n y c h ~ p r z e z ̇ y c ́ ~ w ~ g r o n i e ~ p r z y j a c i o ́ t . ~}$

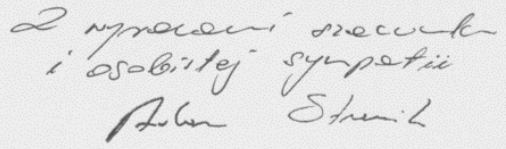

